International Journal of Engineering \& Technology, $7(3.30)(2018)$ 169-173
International Journal of Engineering \& Technology
Website: www.sciencepubco.com/index.php/IJET
Research paper

\title{
Preserving a Healthy Ecohydrology: a Legal Perspective
}

\author{
Rasyikah Md Khalid ${ }^{1 *}$, Ainul Jaria Maidin², Siti Sarah Sulaiman ${ }^{3}$

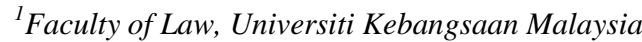 \\ ${ }^{2}$ Ahmad Ibrahim Kulliyah of Law, International Islamic University Malaysia \\ ${ }^{3}$ Faculty of Law, Universiti Teknologi MARA Malaysia \\ *Corresponding author E-mail: rasyikah@ukm.edu.my
}

\begin{abstract}
Ecohydrology focuses on ecological processes within the hydrological cycle. It works under the assumption that an anthropogenically modified catchment or river basin can reverse environmental degradation and enhance the ecosystem service through improved climate cycle, controls erosion, soil formation, water purification, waste treatment and food production. Improved ecosystem services within the hydrological cycle can also serves human's cultural and spiritual aspect as well as in the production of scientific knowledge. There has been call for countries to regulate the use of ecosystem as they are being degraded faster than they can recover. In 2001, the United Nations Environmental Program (UNEP) initiated the Millennium Ecosystem Assessment (MEA) to assess the consequences of ecosystem change for human well-being. It finds that $60 \%$ of 24 ecosystem services examined such as clean water, food, forest products, flood control and provision of natural resources has been badly degraded due to unsustainable development. It is submitted that law can play a role in ensuring preservation of a healthy ecohydrology as a tool used by respective authorities to achieve sustainable development and prevent excessive use of natural resources. This requires a new philosophy on the role of law in ecohydrological protection since environmental legislations fail to punish human activities that had either directly or indirectly disrupt the normal hydrological cycle. An analysis on earth jurisprudence, environmental ethics, equity and justice may elucidate the need to preserve a heathy ecohydrology as its own and other human's right.
\end{abstract}

Keywords: Ecohydrology, Ecosystem Service, Equity, Ethics, Human Right, Jurisprudence.

\section{Introduction}

"Earth provides enough to satisfy every man's need but not every man's greed". Mahatma Gandhi.

Water plays a vital role in social and economic development. It contributes towards agricultural sector and food security; it generates hydroelectric power for energy production. Nevertheless, the role that water in the entire ecosystem has rather been a neglected issue in the development process. As a consequence, rivers have been polluted and killed the aquatic life, groundwater has been over-exploited and sinked the water table, and water catchment forestry has being cut and created erosion, flood and landslide. Development becomes meaningless when fresh water becomes scarce and the ecosystem is being degraded. To date, the price paid for water services enjoyed by human may either reflect the whole true cost of water treatment, half of the cost or none at all. No payment whatsoever has been paid for the ecosystem services that ensure continuous flow of freshwater in the rivers. Payment for ecosystem services (PES) is based on the idea that those who provide ecosystem services will be paid for doing so while those who benefit from it will pay for such provision. It represents a basic conservation contract as it is a voluntary agreements between the provider who will conserve the resource in return for cash, incentives or finance from the user. It solves market failures that ignore any forms of reward or compensation to the providers. However, it is not the aim of the paper to explore on the economic analysis of PES, or the weaknesses of the system in practice. Ra- ther it will explore on the jurisprudential basis for making PES from water resources legally valid based on its ethical and equitable value. The following discussion begins with the role of water in the ecosystem and how human's use of water affects the ecosystem. It briefly explains PES and the types of payment made to water services, elaborates on the jurisprudential, ethical and equitable argument for PES.

\section{Water Ecosystem, Hydrological Cycle and Climate Change}

The discussion on water ecosystem requires an understanding of hydrologic cycle which is fundamental to the study of hydrology. It is simply the process when rain "provides runoff on the land surface, infiltrates into soils, recharges groundwater, discharges into streams, and ultimately, flows out into the oceans from which it will eventually evaporate once again" [1]. Such description corresponds with divine revelation such as the Quran which provides; "It is God Who sends the Winds, and they raise the Clouds: then does He spread them in the sky as He wills, and break them into fragments, until you see rain-drops issue from the midst thereof: then when $\mathrm{He}$ has made them reach such of his servants as $\mathrm{He}$ wills, behold, they do rejoice! (Quran, 30:48).

The complete, natural and undisturbed water cycle provides water not only for human survival but also for the whole ecosystem. Gleick describes that sustainable water use means the act of using water responsibly to support both the ability of human to endure into the future and uphold the integrity of the hydrological cycle and the ecosystems that depend on it. This balancing exercise 
refers to the act of conservation which creates a state of harmony between man and the land and that confers the owner of the land or other natural resources both privileges and obligations [2]. Muhammad et al. reiterate that God reminds human to respect nature and not to disrupt the balance that exists in nature in this verse: "And the sky he has uplifted, and He hath set the balance. That you not transgress with the balance" (Quran, 55: 7-8). Similarly another verse provides: "Corruption has appeared on earth and at sea because of what the hands of men have wrought; in order that God may make them taste the consequences of their actions; so that they might return [to God] (Quran, 30:41).

Indeed, large scale deforestation, industrialization and unsustainable development over the past centuries have caused changes in the atmospheric climate. Scientists argue whether the hydrological cycle will remain uninterrupted and can sustain itself without interruption from the changes caused by human. Linton (2008) argues that the cycle "emerged within a particular set of historical and geographical circumstances" but has been exploited to make way for dam construction to cater for agricultural or hydropower. As such, he doubts whether the cycle can be sustained in the view of the changes made to the natural state of water resources. It is observed that slight changes in the hydrological cycle such as increase rainfall in wetter areas has led to more erosion in catchment areas, raised the turbidity levels of water and affected drinking water quality (Zakaria, 2010). Instability in the ecosystem will later change soil quality and lead to emergence of new pests and diseases that will disrupt agricultural sector (Leopold, 1949).

Scientists believe that the warming climate has increased evaporation rates hence increased precipitation (IPCC, 2007). As a result, the rain continues to come down but in a heavier scale. The warming climate has also expedited ice melting and increase sea level. This further intensifies the hydrological cycle with more evaporation and precipitation. The overall impact of climate change essentially started with changes in the solar inputs, the hydrological cycle as well as in the atmospheric composition and circulation. These lead to more heat waves and frequent hot days and night, more drought and increase in intense tropical cyclone. In the near future, the IPCC report predicted more contraction of snow cover areas. Ironically, although heavy precipitation is anticipated, IPCC also projects gradual decrease of water resources in many arid and semi-arid areas. Thus, dry land will become drier while wet land will get more rain and experience more water related problems like flood, landslide and pollution [3].

Increasing greenhouse gases, especially carbon dioxide have contributed to warming earth surface and increase evaporations. Nevertheless, the global water balance can only be achieved if evaporation from oceans corresponds with the amount of precipitation. The greenhouse gases will continue to concentrate in the atmosphere, causing higher sea-surface temperature, increase evaporation rate and accelerate the normal hydrological cycle. The IPCC predicted that global warming by $4^{\circ} \mathrm{C}\left(7.2^{\circ} \mathrm{F}\right)$ can increase global precipitation by about 10 percent and such increase is more likely to come in a form of a short but heavier rainfall, rather than a more frequent rainfalls for a longer duration. To reduce such impact, efficient management of water resources is urgently needed for "better hydrologic and nutrient cycles, generate feedstock for industry, produce ecosystem benefits and increase food security" [4].

Water is also vitally needed in the energy sector for oil extraction and power generation, hydropower and other renewable supplies of energy such as biofuel. In one of its studies, the GWSP argues that water-energy-food security nexus can influence river basin management, especially those which are trans-boundary. As a result, governments must understand the characteristics and interactions of their river basins as well as improve their water governance and management. Political conflict or instability for instance can delay economic and social development of the basin especially in riparian states. The negative effects of this scenario are changing the role that rivers play in the societies as well as adversely impact the ecosystem services. Thus the acceleration of the hydrological cycle has created several impact that raises concern for water, food and energy security.

\section{Payment for Ecosystem Services (PES)}

The Millennium Ecosystem Assessment examined 24 ecosystem services such as clean water, food, forest products, flood control and provision of natural resources, and found that $60 \%$ of them has been badly degraded due to development. This is partly contributed by the low or none economic value attached to the ecosystem despite the services that they provide [5]. As the late Aldo Leopold rightly puts it in his essay The Land Ethic: "Of the 22,000 higher plants and animals native to Wisconsin, it is doubtful whether more than 5 per cent can be sold, fed, eaten, or otherwise put to economic use. Yet these creatures are members of the biotic community, and if (as I believe) its stability depends on its integrity, they are entitled to continuance" [2]. Thus, man must protect the vital ecosystem to ensure his own survival and sustenance.

PES is seen as a workable mechanism to put the correct value of the services when used by human. Thorpe et.al define it as "quantifiable or qualitative benefits of ecosystem functioning to the overall environment, including the products, services and other benefits humans receive from natural, regulated, or otherwise perturbed ecosystems". Alternatively, Mauerhofer et al., [6] argue that PES focuses on provider-based economic approaches so that the provider of services will be paid or compensated by those who use or benefit from the services. It represents a basic conservation contract as it is a voluntary agreement between the provider who will conserve the resource in return for cash, incentives or finance from the users. Wunder [7] defines PES as:

"(a) a voluntary transaction where (b) a well-defined ecosystem service or a land use likely to secure that service (c) is being 'bought' by a (minimum one) service buyer (d) from a (minimum one) service provider (e) if and only if the service provider secures service provision (conditionality)".

PES aims to capture both direct and indirect values of ecosystem services through economic techniques in environmental valuation such as the market cost approach or the replacement cost approach $[8,9]$. The market cost approach will utilise directly observed prices and costs from actual markets related to the provision of an environmental good or services as a representative to the value of that environmental good or service; while the replacement cost method uses the costs of replacing an environmental service as the value of that service $[8,9]$. Both, the market cost and replacement cost approaches have been used to value the cost of soil erosion in Sleman, Java [10], and in Sri Lanka [11]. Value can also be attached to the costs associated with mitigation of environmental damage and this was used in valuing storm protection services in Thailand's mangroves forest [12].

Rivers play an important role in the ecosystem as they often run across borders and are regulated by the hydrological cycle. Nevertheless many rivers have been degraded, diverted, modified or straightened to give way for development and have serious implications on the ecosystem services. Gilvear et. al. [13] explain, "Hundreds of years of modifications in fluvial corridors and the catchments they drain have altered the nature of ecosystem services" with impacts on "flow, quality and structure of water courses, from diffuse pollution and invasion by non-native species". As such, many rivers have undergone rehabilitation process to enhance the ecosystem services $[13,14]$ but the successful rate varies based on an accurate nexus assessment of hydrological patterns, fluvial disturbance and ecological responses [14].

The extensive role of river in ecosystem has led scientists to believe that economic value must also be given to the eco-hydrology and to establish a new ecosystem services approach in river basin management. When economic value is given to freshwater and charged in the water tariff, appropriate signals could be send to users on water scarcity and conservation. River, land and forests 
are the integral part of the ecosystem as it serves all aspect of the ecosystem services i.e. supporting, regulating, provisioning and cultural, and their conservation must be appropriately calculated to represent the value of their services. In Scotland, the Scottish Water has developed the Sustainable Land Management (SLM) Incentive Scheme to protect drinking water sources in Scotland. Under the scheme, land managers in six river catchments around Scotland can apply the SLM incentives of up to GBP20000 per annum to improve and protect water sources in the catchment beyond what the managers are legally bound to do. This includes pesticide control, reducing surface flow, ditch modification, peat land restoration and better field management. The incentive is to the land managers because they cannot be expected to cover the cost of protecting drinking water source through sustainable farming (Scottish Water, 2016). Similar approach has been used in New York City (NYC) as early as 1800 s when NYC pays Delaware District within the New York region and the state of Connecticut for protecting watersheds that ensures sustainable water supply for eight million residents in NYC.

The New Work City and Delaware District case demonstrate that in a federal state, jurisdiction over river, land and forest normally falls under the state government as the owner of these resources. Nevertheless the federal government may face difficulty in requesting state government to conserve forest in ensuring sustainable ecosystem services. On many occasion, federal orders have not received full support from the state government because logging or mining are their main source of income. In addition, permission for development and industrialisation also brings more income regardless the impacts on the ecosystem of the downstream states. The present dispute in Malaysia on whether the state of Penang should pay conservation cost to the state of Kedah is an interesting case study on the duty of upstream and downstream state in protecting water ecosystem. The Penang government insists that they will not pay anything since they abstract water from the Penang side of Muda River; and conservation cost will only be paid if the Kedah government permanently reserved the Ulu Muda forest [15].

The present minimal value attached to raw water does not reflect the value of water ecosystem. In the state of Selangor in Malaysia for instance, the rate for water abstraction is $\mathrm{RM} 0.05 / \mathrm{m}^{3}$ or USD0.01 for commercial use. This clearly is not equivalent to the value of maintaining forest catchment that ensures continuous water supply. The price for raw water transferred from the state of Pahang to Selangor has been increased to RM0.10/m3 or USD0.02 and Pahang will get RM70 millions or USD17.7 million per year from the water transfer. This can still be regarded as minimal compared to the ecosystem services provided by the forest, but this has increased the value of fresh water supply and more must be paid if more need to be done to protect the catchment areas. As such, if the federal government is serious about ensuring continuous water supply, it must pay the correct price to the state governments for protecting the catchment areas. Questions remains as to what is the rate for such ecosystem service, who benefits and how much benefits do they receive. As water is closely linked with land, the rate may depend on the extent of the land use and the number of stakeholders involved. Thus, the rate differs between upstream and downstream users and varies from one locality to another. More research is then needed to get the science and equation right and to ensure that the services are delivered with or without changes in the land use.

\section{Earth Jurisprudence}

Earth jurisprudence is a philosophy of law that seeks to understand the relationship between law and living things based on different disciplines like ecology, sociology and economy. It redefines the relationship between human and the environment through an ecocentric rather than anthropocentric perspective $[16,17,18]$. It requires a new thinking of the law to re-value the role of nature in the community whereby human currently assumes the role as the one and only stakeholder who treats nature as mere chattel and has no obligation whatsoever towards them [2, 17]. It promotes an eco-centric evaluation of human and earth development since nature has the right to be, to habitat and to participate in the evolution of the earth community [19].

Ecologist Aldo Leopold argued that changes will not take place in the way man regards the ecosystem services as it requires "intellectual emphasis, loyalties, affections, and convictions" and despite numerous calls for conservation, the result remains trivial since "philosophy and religion have not yet heard of it" [2]. Within the legal study, jurisprudence refers to the philosophy of law but it only focuses on the rights and obligation of a human towards another human, but not to the entire ecosystem. When Aldo Leopold wrote "The Land Ethics" he felt that man continues to degrade the land as land is a property which man has no obligation towards it. He proposed for a more ethical behaviour towards land but that does not create a legal obligation for man to conserve the land and the entire ecosystem for the services they provide.

Earth jurisprudence has been established in a religion like Islam which seek human being to see the sign and interconnectedness of nature and life as told in this Quranic verse:

Allah sends down water from the sky and by it brings the dead earth back to life. There is certainly a Sign in that for people who hear. There is instruction for you in cattle. From the contents of their bellies, from between dung and blood, we give you pure milk to drink, easy for drinkers to swallow. And from the fruit of the date palm and the grapevine you derive both intoxicants and wholesome provision. There is certainly a Sign in that for people who use their intellect. Your Lord revealed to the bees: 'Build dwellings in the mountains and the trees, and also in the structures which men erect. Then eat from every kind of fruit and travel the paths of your Lord, which have been made easy for you to follow'. From inside them comes a drink of varying colours, containing healing for mankind. There is certainly a Sign in that for people who reflect (Quran: 16: 65-69).

Islamic environmental jurisprudence is supported by Islamic principles of unity (Tawhid) stewardship or trusteeship (Khalifa) and accountability or responsibility (Akhirah). In this regard, unity is achieved when man as a trustee maintains the integrity of nature; and he will be accountable if he fails to keep nature in harmony. Thus when a man revive a piece of land he will own property in the land (Ihya'Al Mawat) but Allah remains the ultimate owner of everything. The concept of trusteeship also applies to the leaders as they can establish special reserves for conservation (Hima) or inviolable zones (Harlm). This means that collective interest may prevail over individual property and conservation zone shall be established in areas adjacent to natural resources and other public utilities.

Theologian perspectives for environmental stewardship or guardianship has been the key argument by the natural law school in upholding environmental sustainability amidst fast developing world. Stone stressed that it is wrong to say that "streams and forests cannot have standing because streams and forests cannot speak" but man has allowed lawyers to speak for corporations, estates and incompetents. This mean that man must be the guardian of every living thing that has intrinsic value in its self as of right just like the right created for other non-living thing like corporation. To be operational, such right must satisfies three criteria: "first, that the thing can institute legal actions at its behest, second, that in determining the granting of legal relief, the court must take injury to it into account; and, third, that relief must run to the benefit of it".

The religious requirement of respecting nature should be incorporated into any positive law as it is natural and rational. In contrast to Immanuel Kant who perceived man as the lawgiver, Thomas Aquinas believed that a prudent lawgiver should be guided by natural law to give an informed decision to the common good of any living things [20]. This philosophical standpoint has been depreciated when positivists led the promulgation of modern envi- 
ronmental law while new polluter-pay-principle allow pollution to the detriment of ecosystem. As Bosselmann [21] rightly puts; "the dominance of positivism leads to ecological ignorance while the anthropocentric, resource-oriented and non-integrative approach tend to foster industrialization rather than changing it". Thus there is an urgent need to reinforce the ecological principle back to the legal system to redefine by means of PES the duty to protect the integrity of the ecosystem.

\section{Environmental Ethics and Intergenerational Equity}

Besides efforts to reincarnate the law of nature through environmental jurisprudence, scientists, ecologists and environmentalists have continuously argued on why men need to respect nature and not to disrupt environmental flow. This has been referred to as the non-anthropocentric ethics as it requires human behavior and environmental policy to be in harmony with nature and not just for the benefit of human [22]. Aldo Leopold for instance introduced the eco-centric environmental ethics and argued that man underestimate the interconnectedness of nature and rebutted the general belief that predators must be exterminated to increase living herds. He developed the biological pyramid to explain that nature has its own way of working and that land is not a mere property but a living organism that can be healthy or unhealthy, injured or killed and "is a fountain of energy flowing through a circuit of soils, plants and animals" [2].

Besides eco-centric ethics, other environmentalists like Albert Schweitzer and Paul Taylor developed the bio-centric or lifecentered ethics as an argument that men need to respect nature as all lives organism other that human being have moral standing. Albert Schweitzer explained as early as in 1949 that 'man is ethical only when life, as such, is sacred to him, that of plants and animals as that of his fellow men, and when he devotes himself helpfully to all life that is in need of help. The ethic of the revelation of man to man is not something apart by itself; it is only a particular relation which results from the universal one' [23].

One of the younger generation of bio-centric advocate, Paul Taylor regards "every species counts as having the same value in the sense that it is deemed to be prima facie deserving of equal concern and consideration on the part of moral agent' i.e. the human community. He developed four rules of how human behave towards nature which are the rule of non-maleficence, the rule of non-interference, the rule of fidelity and the rule of restitutive justice; thus man has a duty not to injure nature, limits its freedom or abuse their trust, and will compensate them if breached [24]. In this regard, conflict will inevitably exist between the above duties and the right of man to consume other living resources or to exterminate other animal in order to survive. Towards this end, he introduces five principles which are the principle of self-defense, the principle of proportionality, the principle of minimum wrong, the principle of redistributive justice and the principle of restitutive justice [24]. It is understood that the main thrust of his arguments and other non-anthropocentric theorist are that other living things deserve some moral concern and respect. This is different from the normal anthropocentric like John Passmore [25] who views man's duty to respect nature originates from the duty he owes to one another as human beings.

The question of duty that man owes towards another and towards nature generates the idea that such duty arises as he borrows the nature from future generation. This is referred to, as Edith BrownWeiss coined it, intergenerational equity and has now been used as a point of argument in cases like the famous Oposa v Factoran in the Philippines. By intergenerational equity she means:

We, the human species, hold the natural environment of our planet in common with all members of our species: past generations, the present generation, and future generations. As members of the present generation, we hold the Earth in trust for future genera- tions. At the same time, we are beneficiaries entitled to use and benefit from it [26].

The main idea of the principle of intergenerational equity is to ensure that the present generation should not abuse the ecosystem so as to deprive the future generation of its benefit. The theory concerns not only with relationship between generations but also with nature conservation. Brown-Weiss argues that present generation must ensure 'conservation of options', 'conservation of quality' and 'conservation of assess' they have inherited from the past generation for the benefit of future generation [26]. Nevertheless the fate of future generation is not being properly considered in decision making process albeit the impact those decisions may have on the ecosystem and later onto the future generation.

\section{PES Compliments Legal Principles}

Two legal principles are mainly employed to protect the environment: the polluter pay principle and the precautionary principle. Both are distinct in term of the stage where the principles can be implemented. The polluter pay principle is invoked in the event of pollution and the polluter bears "the expenses of carrying out pollution prevention and control measures to ensure that the environment is in an acceptable state" [27]. In contrast, the precautionary principle incorporates the old notion "better safe than sorry" to the effect that if there are "threats of serious or irreversible damage, lack of full scientific certainty shall not be used as a reason for postponing cost-effective measures to prevent environmental degradation". Sadeleer [28] argues that precautionary should not be labelled as principle but merely an approach. This is due to the fact that there still exist different understandings of how to incorporate precaution in the absence of scientific uncertainty. Nevertheless it is the uncertainty that organizes precaution as a principle to avoid the risks from much wider and diffuse impacts [29]. At this point, precautionary principle resembles the preventative principle which implies that man has the duty to ensure that activities within their control do not damage the environment of another. PES is seen as a new tool to strengthen both the polluter pay principle and the precautionary principle. Mauerhofer et al. [6] argue that PES compliments the polluter pay principle in situation where no regulations clearly impose a duty on the polluter, or where existing regulations are believed to be not sufficiently thought through, and where PES offers incentives for the best environmental practice. It is also noted that PES programs normally operates in areas where command-and-control regulations already exist [6] and its financial element provides "the carrot" that makes the "stick of polluter pay principle more palatable". In another study, German et al. [29] argues that PES employs precautionary principle to facilitate stakeholders "to anticipate the likely social and environmental outcomes of different scenarios, to negotiate socially-optimal scenarios and to design incentive and/or regulatory schemes to foster mutually agreed outcomes". In this respect, precautionary principle helps to identify the "stakes" and "tradeoffs" of a PES program which is useful for the planning of a proposed land use change [29]. This shows that PES strengthened the implementation of legal principles designed for environmental protection.

\section{Conclusion}

Man must pay for the ecosystem services. If they are free, man will use them excessively to their deterioration and that limits other people's enjoyment of ecosystem services which is a right of any human. PES is a viable tool that ensured better conservation and enhancement of ecosystem but its implementation must be legally strengthened. This can be done through the concept of guardianship and man needs to protect nature based on intergenerational equity and justice. Ethically, man should respect nature as they respect other human being, as nature has the right to be, right 
to habitat and right to participate in the evolution of the earth community. Thus the fulfilment of a man's right is dependent upon the fulfilment of the rights of nature since man cannot enjoy his life if the environment is destroyed. PES corrects the traditional economic market that fails to put an appropriate value to the ecosystem services, compliments existing legal principles for better protection of the ecosystem thus enhance its services.

\section{Acknowledgement}

The authors would like to thank the Universiti Kebangsaan Malaysia and the Ministry of Higher Education of Malaysia for funding this research (Grant No. FRGS/1/2017/SSI10/UKM/02/1).

\section{References}

[1] Linton J (2008), Is the Hydrologic Cycle Sustainable? A HistoricalGeographical Critique of a Modern Concept. Annals of the Association of American Geographers 98(3), 630-649.

[2] Leopold A (1949), A Sand County Almanac: With Other Essays on Conservation from 'Round River'. New York: Oxford University Press.

[3] Zakaria S (2010), Impact of Climate Change on Water: Focus Malaysia. Association of space Explorers (ASE) XXIII Planetary Congress. Putrajaya Malaysia.

[4] Global Water System Project (2012).

[5] Dunn, Helen (2011), Payments for Ecosystem Services, DEFRA Forest Stewardship Council.

[6] Mauerhofer V, Hubacek K \& Coleby A (2013), From Polluter Pays to Provider Gets: Distribution of Rights and Costs under Payments for Ecosystem Services. Ecology and Society 18(4), 41.

[7] Wunder S (2007), The Efficiency of Payments for Environmental Services in Tropical Conservation. Conservation Biology 21(1) 48-58.

[8] Farber S, Costanza R, Childers DL, Erickson J, Gross K, Grove M, Hopkinson CS, Kahn J, Pincetl S, Troy A, Warren P \& Wilson M (2006), Linking Ecology and Economics for Ecosystem Management. BioScience 56(2), 117-129.

[9] Costanza R (2006), Nature: Ecosystems without Commodifying Them. Nature 443(7113) 749.

[10] Moller A \& Ranke U (2006), Estimation of the On-farm-costs of Soil Erosion in Sleman, Indonesia. In: Martin-Duque JF, Brebbia CA, Emmanouloudis DE, Mander U \& (Eds.), Geo-Environment and Landscape Evolution Ii - Evolution, Monitoring, Simulation, Management and Remediation of the Geological Environment and Landscape 43-52.

[11] Gunatilake HM \& Vieth GR (2000), Estimation of on-site cost of soil erosion: A comparison replacement and productivity change methods. J of Soil \&Water Conservation 55, 197-204.

[12] Barbier EB (2007), Valuing ecosystems as productive inputs. Economic Policy 179-229.

[13] Gilvear DJ, Spray CJ \& Casas-Mulet R (2013), River Rehabilitation for the Delivery of Multiple Ecosystem Services at the River Network Scale. Journal of Environmental Management 126, 30-43.

[14] Arthington AH, Naiman RJ, Mcclain ME \& Nilsson C (2010), Preserving the Biodiversity and Ecological Services of Rivers: New Challenges and Research Opportunities. Freshwater Biology 55, 1 16.

[15] The Malay Mail (2016) Bar logging at all water catchments, Putrajaya told, http://www.themalaymailonline.com/malaysia/article/barlogging-at-all-water-catchments-putrajayatold\#sthash.QgD0ObIL.dpuf

[16] Alexander S (2010), Earth Jurisprudence and the Ecological Case for De-growth. The Journal Jurisprudence 131-148.

[17] Koons JE (2012), At the Tipping Point: Defining an Earth Jurisprudence for Social and Ecological Justice. Layola Law Review 58, 349-390.

[18] Schillmoller A \& Pelizzon A (2013), Mapping the Terrain of Earth Jurisprudence: Landscape, Thresholds and Horizons Environmental and Earth Law Journal 3, 1-32.

[19] Berry T (1999), The Great Work: Our Way into the Future. New York: Bell Tower Press.

[20] Aquinas T (1952), Summa Theologica. Translated by Father of the English Dominican Province. Revised by Daniel J. Sullivan. Encyclopaedia Britannica, Inc.
[21] Bosselmann K (2008), The Principle of Sustainability: Transforming Law and Governance. Surrey: Ashgate Publishing Limited.

[22] Stenmark M (2002), Environmental Ethics and Policy Making. Ashgate, Burlington.

[23] Schweitzer A (1949), Out of My Life and Thought: An Autobiography, Holt, Rinehart \& Winston, New York 158-159, as quoted in Stenmark, Environmental Ethics and Policy Making.

[24] Taylor P (1986), Respect for Nature: A Theory of Environmental Ethics, Princeton University Press, Princeton 172-187, as quoted in Stenmark, Environmental Ethics and Policy Making.

[25] Passmore J (1974), Man's Responsibility for Nature. Ecological Problems and Western Traditions, Gerard Duckworth and Co. Ltd. London.

[26] Brown-Weiss E (1992), Intergenerational Equity: A Legal Framework for Global Environmental Change. Environmental Change and International Law: New Challenges and Dimensions. Tokyo: United Nations University Press.

[27] OECD (1974), Recommendation on the Implementation of the Polluter Pay Principle.

[28] Sadeleer ND (2007), Origin, Status and Effects of the Precautionary Principle. Implementing the Precautionary Principle: Approaches from the Nordic Countries, EU and USA. London: Earthscan.

[29] German L, Villamor G, Twine E, Velarde SJ \& Kidane B (2009), Environmental Services and the Precautionary Principle: Using Scenarios to Reconcile Conservation and Livelihood Objectives in Upper Catchments. Journal of Sustainable Forestry 28 (3-5), 368394. 